\title{
パーマロイ-鉄酸化物複合体の水熱反応焼結
}

\author{
中川隆広・神野公行*.吉村昌弘・宗宮重行 \\ $\left(\begin{array}{l}\text { 東京工業大学 工業材料研究所 } \\ * \text { 三菱製鋼 }(\text { 株) }\end{array}\right.$
}

\section{Hydrothermal Reaction Sintering of Permalloy-Iron Oxide Composite}

\author{
Takahiro NAKAGAWA, Kimiyuki KAMINO*, Masahiro YOSHIMURA \\ and Shigeyuki SŌMIYA \\ Research Laboratory of Engineering Materials, Tokyo Institute of Technology \\ 4259, Nagatsuta, Midori-ku, Yokohama-shi 227 \\ * Mitsubishi Steel Mfg. Co., Ltd.
}

\begin{abstract}
Hydrothermal reaction sintering is one of the methods to prepare oxides ceramics. Metals, intermetallic compounds or alloys are sealed in a Pt capsule with water. On heating they react with high pressure high temperature water, and produce metal oxides and hydrogen gas. At high temperatures, hydrogen gas diffuses out of the capsule, then the capsule containing oxide powders is compressed by outside gas pressure. The oxide powders, therefore, can be sintered in the capsule as in HIP (hot isostatic pressing). By this method, we can obtain a metal-oxide composite by the control of water to metal or alloy ratio in the capsule. The known quantities of alloy powders; water-atomized permalloy powder ( $\mathrm{Fe}-47 \mathrm{rot} \% \mathrm{Ni}<\# 100$, and $\mathrm{Fe}$ 36 wt\% $\mathrm{Ni}<\# 100$ ) and redistilled water were hermetically sealed with an electric arc in a platinum capsule $2.7 \mathrm{~mm}$ inside diameter, $0.15 \mathrm{~mm}$ thick and $35 \mathrm{~mm}$ long. This capsule was treated at $100 \mathrm{MPa}, 800^{\circ}-1000^{\circ} \mathrm{C}$, for $10-240 \mathrm{~min}$ in a high pressure high temperature apparatus using Ar gas as pressurizing medium. The produced sintered ceramics were examined by X-ray diffraction, optical and scanning electron microscopy, and energy dispersive spectroscopy $(E D S)$. The products are composed of oxide matrix and disperse alloy phase. According to the X-ray diffraction and EDS, the oxide phase contained only iron as cations. Selective oxidation of iron, therefore, was occurred under the hydrothermal conditions as well as in air. Magnetite and wiistite were observed as iron oxide phase. The ratio of magnetite and wiristite is dependent on temperature, quantity of $\mathrm{H}_{2} \mathrm{O}$, and time. When a specimen is treated at high temperatures, for a long time, or with a little quantity of $\mathrm{H}_{2} \mathrm{O}$, wiustite phase is a main phase. When the opposite conditions, magnetite is a main phase. This tendency results from both the kinetics and the thermodynamics. The composites showed superposed magnetic properties of $\mathrm{Fe}_{\mathrm{e}} \mathrm{Ni}$ alloy and iron oxides, magnetite and/or wiistite.

[Received February 1, 1986]
\end{abstract}

Key-words : Permalloy-iron oxide composite, Hydrothermal reaction sintering, Magnetite, Wüstite, Selective oxidation

\section{1. はじめに}

水熱反応焼結とは水熱反応を応用する酸化物の焼結方 法である11．この方法では金属カプセルに水と金属ある いは合金粉末を封入し, 高温高圧下で反応させることに よって酸化物を作る. 副生成物である水素は金属カプセ ル壁中を拡散して系外に排出されるので外圧はカプセル 内の酸化物粉末に働き HIP と同様の条件となってその 焼結を促進させる. 今までにこの水熱反応焼結でジルコ ニア $^{2)}$, クロミア ${ }^{3)}$, ランタンクロマイト4), マグネタイ ト5)などの研究がなされている.この方法において水の 量をすべての金属が酸化する量よりも少なくすることに よって金属と酸化物の複合焼結体を得ることが可能であ る. 今回 $\mathrm{Fe}-\mathrm{Ni}$ 合金粉末を水熱反応焼結させることに よってパーマロイ-鉄酸化物複合焼結体を得たので報告 する.

\section{2. 実 験}

出発試料には Fe-47 wt \% Ni, 及び Fe-36 wt \% Ni, 水
アトマイズ粉（粒径 100 メッシュ以下）を用いた。この 合金粉末と所定量の再蒸留水を内径 $2.7 \mathrm{~mm} \phi$, 長さ 35 $\mathrm{mm}$, 肉厚 $0.15 \mathrm{~mm}$ の白金カプセル中に溶封した。この カプセルを温度 $800^{\circ} \sim 1000^{\circ} \mathrm{C}$, 圧力 $100 \mathrm{MPa}$ で 10 $240 \mathrm{~min}$ 加熱加圧処理した. 装置はアルゴンガス圧縮高 圧高温炬を用いた。生成した焼結体は樹脂にうめ込んだ 後研磨処理をした.この試料の光学顕微鏡観察, 画像解 析, X 線回折を行い, カーボン蒸着後 EPMA 観察を行っ た.

\section{3. 結 果}

図 1 は得られた複合体の切断面顕微鏡写真である.灰 色のマトリックスが酸化物相であり，白い分散相が金属 相である. 加える $\mathrm{H}_{2} \mathrm{O}$ の量を増やすと酸化物相が増え ている．酸化物相中の黒い部分は気孔である．この気孔 の面積率を画像解析で測定した結果が図 2である.100 $\mathrm{MPa}, 1000^{\circ} \mathrm{C}, 60 \mathrm{~min}$ の処理で気孔率は $1 \%$ 以下になっ ている. $800^{\circ} \mathrm{C}$ においては白金カプセル壁中の水素の拡 

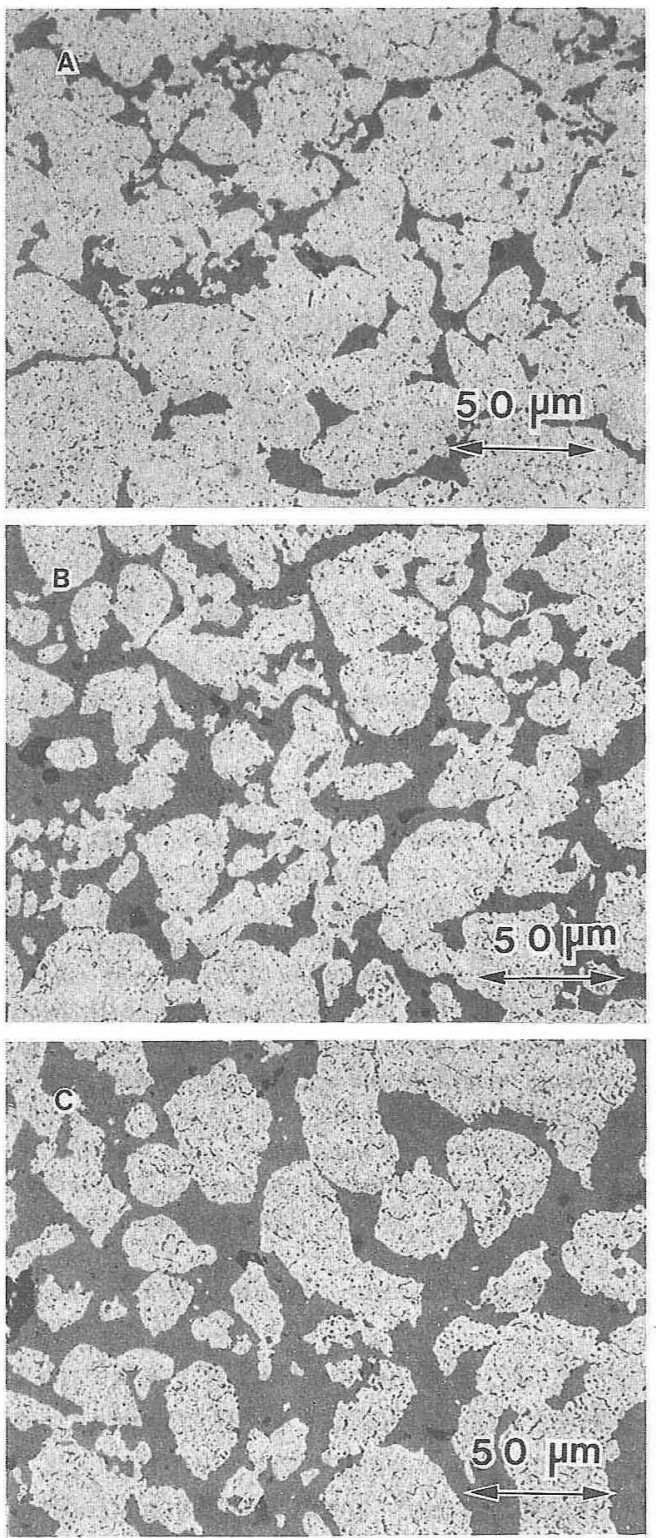

Fig. 1. Optical photomicrographs of the polished sur face of the products; Fe-47 wt \% Ni, $100 \mathrm{MPa}, 1000^{\circ} \mathrm{C}$, $1 \mathrm{~h} ;$ (A) $5 \mathrm{wt} \% \mathrm{H}_{2} \mathrm{O}$, (B) $10 \mathrm{wt} \% \mathrm{H}_{2} \mathrm{O}$, (C) $15 \mathrm{wt} \%$ $\mathrm{H}_{2} \mathrm{O}$.

散速度が小さいこと，酸化速度が小さいこと，またその ために $\mathrm{H}_{2} \mathrm{O}$ の残留が起こりカプセルの内圧が高いこと などにより,気孔率が減少するのに時間がかかっている。 また $\mathrm{Fe}-47$ wt\% $\mathrm{Ni}$ 粉末を $\mathrm{H}_{2} \mathrm{O}$ なじ $100 \mathrm{MPa}$, $1000^{\circ} \mathrm{C} ， 60$ min の HIP 処理を行った場合は気孔のほと んどない焼結体が得られた。

図 3 は $\mathrm{Fe}-36$ wt \% Ni, 20 wt \% $\mathrm{H}_{2} \mathrm{O}, 100 \mathrm{MPa}, 1000^{\circ} \mathrm{C}$, $60 \mathrm{~min}$ 処理試料の走督型電子顕微鏡 (SEM) 像及び EPMA 元素分析の結果である。灰色の酸化物相には Ni がほとんビ存在せず，Fe の選択的酸化がこの水熱条件

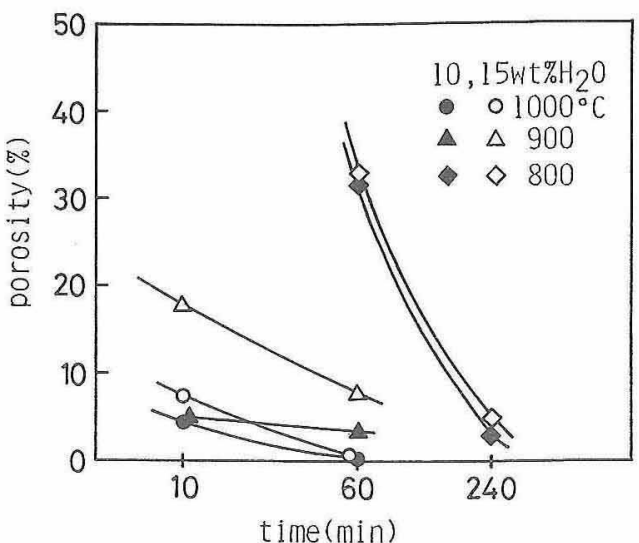

Fig. 2. Porosity by image analysis of magnetite-wistite- $(\mathrm{Fe}-\mathrm{Ni})$ composites under $100 \mathrm{MPa}$ at conditions indicated.

でも大気中の酸化と同じように起こっていることが分か る.X線回折の結果でも酸化物は鉄の酸化物だけが確 認され、ニッケルの酸化物は確認されなかった。

酸化物相中のマグネタイト $\left(\mathrm{Fe}_{3} \mathrm{O}_{4}\right)$ とウスタイト ( $\mathrm{FeO}) の$ 量比をX線回折線の積分強度比で表した結 果が図4である。温度が低いほど，処理時間が短いほど， また加える $\mathrm{H}_{2} \mathrm{P}$ の量が多いほどマグネタイトの量が増 加している。故に温度, 時間, $\mathrm{H}_{2} \mathrm{O}$ の量の 3 因子を制 御することにより，マグネタイトとウスタイトの量比を 制御することが可能である。

図 5 はマグネタイトとウスタイトの 2 相が確認された 試料の SEM 写真である，図中濃い灰色部 (M)·がマグ ネタイトであり，薄い灰色部(W) がウスタイトである。 同定は EPMA でFe $L \alpha$ 線と Fe $L \beta$ 線を測定し，その 強度比を比較することによって行った ${ }^{6)}$. 鉄の然気中酸 化では酸化物は金属に近い方からウスタイト，マグネタ イト、ヘマタイトの順で生成することが知られているが， 本荚験の試料では図 5 (A) のようにウスタイトと合金 相の間にマグネタイトがはさまれている例が多く，予測 された結果とは逆になっている。粒界割れによる $\mathrm{H}_{2} \mathrm{O}$ の進入が原因の一つと考えられるが，明確な原因は不明 である。また図 5 (B) のようにウスタイト中に折出相 の形でマグネタイトが存在している例もあった。これは 冷却中に折出したものと考えられる。

振動試料型磁力計 (VSM) による本研究で得られた 複合体の磁化曲線を図 6 に示す。飽和磁化 $\left(\sigma_{10 \mathrm{~K}}\right)$ は出 発試料 (a) Fe-47 wt\% Ni で $136 \mathrm{emu} / \mathrm{g}$ パーマロイー マグネタイト複合体 (b) で $122 \mathrm{emu} / \mathrm{g}$ ，パーマロイーウ スタイト複合体 (c) で $84 \mathrm{emu} / \mathrm{g}$ であった。すなわち 非磁性のウスタイトとの複合体では飽和磁化の減少が著 しい。また (b)，(c) では磁化曲線がわずかにスネ一 ク状になり，保持力 $\left(H_{\mathrm{c}}\right)$ の变化はほとんど認められ なかった。 以上より，複合体の磁気特性はバルクのパー 

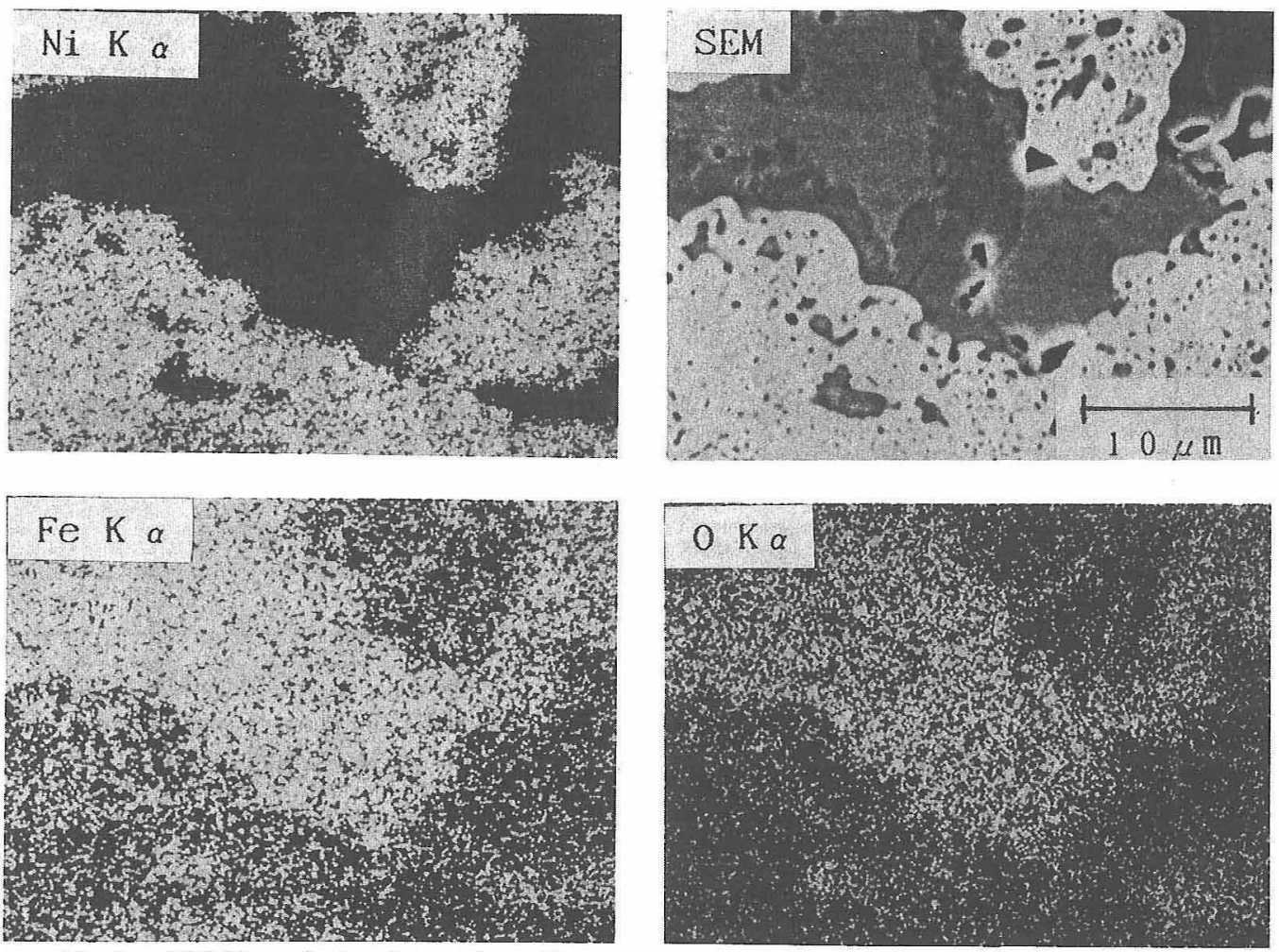

Fig. 3. EPMA analysis of a product; $\mathrm{Fe}-36 \mathrm{wt} \% \mathrm{Ni}, 20 \mathrm{wt} \% \mathrm{H}_{2} \mathrm{O}, 100 \mathrm{MPa}, 1000^{\circ} \mathrm{C}, 10 \mathrm{~min}$.

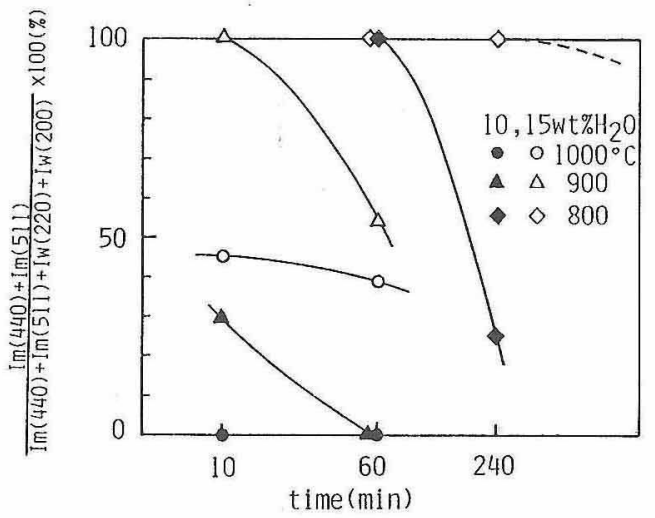

$$
\begin{aligned}
& =<\mathrm{Fe}(\mathrm{OH})_{2}>+\left(\mathrm{H}_{2}\right) \\
& 3<\mathrm{Fe}(\mathrm{OH})_{2}> \\
& =\left\langle\mathrm{Fe}_{3} \mathrm{O}_{4}>+2\left(\mathrm{H}_{2} \mathrm{O}\right)+\left(\mathrm{H}_{2}\right)\right.
\end{aligned}
$$

温度 $300^{\circ} \sim 575^{\circ} \mathrm{C}$

$$
\begin{aligned}
3 & <\mathrm{Fe}>+4\left(\mathrm{H}_{2} \mathrm{O}\right) \\
& =\left\langle\mathrm{Fe}_{3} \mathrm{O}_{4}\right\rangle+4\left(\mathrm{H}_{2}\right)
\end{aligned}
$$

温度 $>575^{\circ} \mathrm{C}$

$$
\begin{gathered}
<\mathrm{Fe}>+\left(\mathrm{H}_{2} \mathrm{O}\right) \\
=<\mathrm{FeO}>+\left(\mathrm{H}_{2}\right) \\
3<\mathrm{FeO}>+\left(\mathrm{H}_{2} \mathrm{O}\right) \\
=<\mathrm{Fe}_{3} \mathrm{O}_{4}>+\left(\mathrm{H}_{2}\right) \\
2<\mathrm{Fe}_{3} \mathrm{O}_{4}>+\left(\mathrm{H}_{2} \mathrm{O}\right) \\
=3<\mathrm{Fe}_{2} \mathrm{O}_{3}>+\left(\mathrm{H}_{2}\right)
\end{gathered}
$$

ray diffraction in oxide phases by hydrothermal reaction sintering from $\mathrm{Fe}-47 \mathrm{wt} \% \mathrm{Ni}$ under $100 \mathrm{MPa}$ at conditions indicated.

マロイと鉄酸化物の特性の重ね合わせとして表れてお り，複合化による特別な相互作用は表れていないことが 分かった。

\section{4. 考察}

$\mathrm{Fe}$ と $\mathrm{H}_{2} \mathrm{O}$ を反応させると次のような酸化反応が進行 する7).

温度 $<300^{\circ} \mathrm{C}$

$$
<\mathrm{Fe}\rangle+2\left(\mathrm{H}_{2} \mathrm{O}\right)
$$

ここで（），く>はそれぞれ気体，固体である，い ま $300^{\circ} \mathrm{C}$ 以上の反忘を考光る。なお（4) 式，(5) 式 の $\mathrm{FeO}$ は不定比組成であり，一般には $\mathrm{Fe}_{1-x} \mathrm{O}$ と表す が、ここでは JANAF' $\mathrm{JAN}^{21}$ 力学デー夕を使うので, そ こに使われている $\mathrm{Fe}_{0.947} \mathrm{O}$ を使用し，(4) 式，(5) 式 をそれぞれ以下のように表す。

$$
\begin{aligned}
& 0.947<\mathrm{Fe}\rangle+\left(\mathrm{H}_{2} \mathrm{O}\right) \\
& =\left\langle\mathrm{Fe}_{0.947} \mathrm{O}>+\left(\mathrm{H}_{2}\right)\right. \\
& 3.807<\mathrm{Fe}_{0.947}>+\left(\mathrm{H}_{2} \mathrm{O}\right) \\
& =1.202<\mathrm{Fe}_{3} \mathrm{O}_{4}>+\left(\mathrm{H}_{2}\right)
\end{aligned}
$$

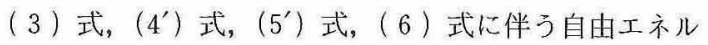




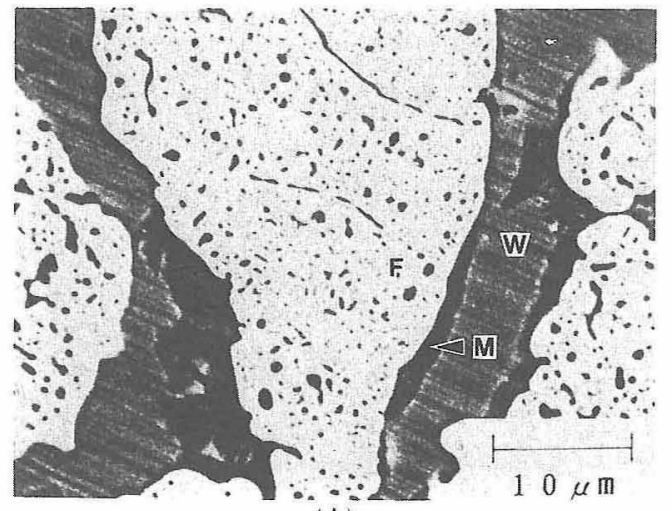

(A)

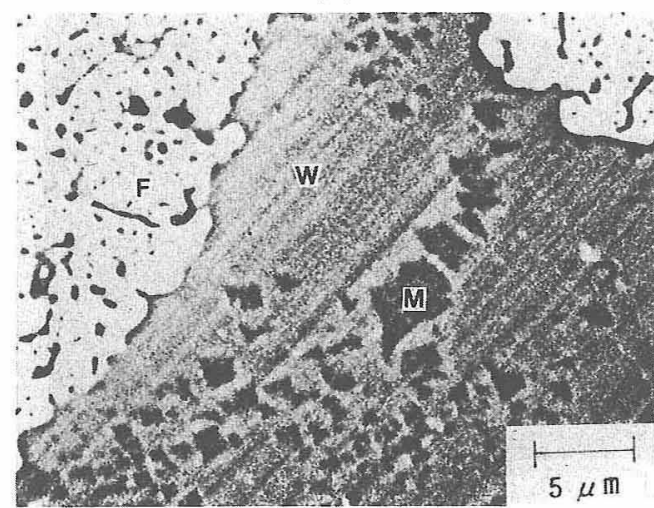

(B)

Fig. 5. SEM photographs of the polished surface of the products ; (A) Fe-47 wt $\% \mathrm{Ni}, 15$ wt\% $\mathrm{H}_{2} \mathrm{O}, 100$ $\mathrm{MPa}, 1000^{\circ} \mathrm{C}, 1 \mathrm{~h}$, (B) $\mathrm{Fe}-36$ wt $\% \mathrm{Ni}, 15$ wt $\% \mathrm{H}_{2} \mathrm{O}$, $100 \mathrm{MPa}, 900^{\circ} \mathrm{C}, 1 \mathrm{~h} ; \mathrm{M}$ : magnetite, W : wistite, F : Fe-Ni alloy.

ギ一変化 $\Delta G_{\mathrm{T}}$ はそれぞれ以下のように表せる。

$$
\begin{aligned}
& \Delta G_{\mathrm{T} 1}=\Delta G_{\mathrm{T} 1}^{\circ}+R T \ln \left\{\left(a_{\mathrm{Fe}_{3} 0_{4}} \cdot p_{\mathrm{H}_{2}}\right) /\left(a_{\mathrm{Fe}^{\circ}} \cdot p_{\mathrm{H}_{2} \mathrm{O}}\right)\right\} \quad(7) \\
& \Delta G_{\mathrm{T} 2}=\Delta G_{\mathrm{T} 2}^{\circ}+R T \ln \left\{\left(a_{\mathrm{Fe}_{0.947} 0^{\circ}} p_{\mathrm{H}_{2}}\right) /\left(a_{\mathrm{Fe}}^{0.947} \cdot p_{\mathrm{H}_{2} \mathrm{O}}\right)\right\}
\end{aligned}
$$

$\Delta G_{\mathrm{T} 3}=\Delta G_{\mathrm{T} 3}^{\circ}+R T \ln \left\{\left(a_{\mathrm{Fe}_{6} 0_{4}}^{1.202} \cdot p_{\mathrm{H}_{2}}\right) /\left(a_{\mathrm{Fe}_{0.947}}^{3.807} p_{\mathrm{H}_{2} \mathrm{O}}\right)\right\}$

$\left.\Delta G_{\mathrm{T}_{4}}=\Delta G_{\mathrm{T} 4}^{\circ}+R T \ln \left(a_{\mathrm{Fe}_{2} 0_{3}}^{3} p_{\mathrm{H}_{2}}\right) /\left(a_{\mathrm{Fe}_{3} \mathrm{O}_{4}}^{2}{ }^{\circ} p_{\mathrm{H}_{2} \mathrm{O}}\right)\right\}(10)$ 反応が平衡の之き $\Delta G_{\mathrm{T}}=0$ であるので，それぞれ

$$
\begin{aligned}
& \Delta G_{\mathrm{T} 1}^{\circ}=R T \ln \left\{\left(a_{\mathrm{Fe}}^{\circ} p_{\mathrm{H}_{2} 0} / a_{\mathrm{Fe}_{3} \mathrm{O}_{4}} \cdot p_{\mathrm{H}_{2}}\right)\right\} \\
& \Delta G_{\mathrm{T} 2}^{\circ}=R T \ln \left\{\left(a_{\mathrm{Fe}}^{0.947} \cdot p_{\mathrm{H}_{2} \mathrm{O}} / a_{\mathrm{Fe}_{0.947} 0^{\circ}} \cdot p_{\mathrm{H}_{2}}\right)\right\} \\
& \Delta G_{\mathrm{T} 3}^{\circ}=R T \ln \left\{\left(a_{\mathrm{Fe}_{0.947}}^{3.807} \cdot p_{\mathrm{H}_{2} \mathrm{O}} / a_{\mathrm{Fe}_{3} 0_{4}}^{1.202} \cdot p_{\mathrm{H}_{2}}\right)\right\} \\
& \Delta G_{\mathrm{T}_{4}}^{\circ}=R T \ln \left\{\left(a_{\mathrm{Fe}_{3} 0_{4}}^{2} \cdot p_{\mathrm{H}_{2} \mathrm{O}} / a_{\mathrm{Fe}_{2} 0_{3}}^{3} \cdot p_{\mathrm{H}_{2}}\right)\right\}
\end{aligned}
$$

純粋な固体物質を基準状態にとると $a_{\mathrm{Fe}}=1, a_{\mathrm{Fe}_{0.9470}}=1$, $a_{\mathrm{Fe}_{3} \mathrm{O}_{4}}=1, a_{\mathrm{Fe}_{2} \mathrm{O}_{3}}=1$ となり，(11) （14）式は次式になる.

$$
\Delta G_{\mathrm{T} i}^{\circ}=R T \ln \left(p_{\mathrm{H}_{2} \mathrm{O}} / p_{\mathrm{H}_{2}}\right)_{i}, \quad(i=1,2,3,4)
$$

各反応の $\Delta G_{\mathrm{T}}^{\circ}$ を JANAF のデータから求め, 温度 $T$ に

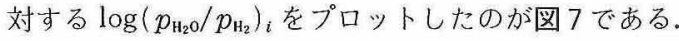
ここで $\mathrm{Fe}-\mathrm{Fe}_{0.947} \mathrm{O}-\mathrm{Fe}_{3} \mathrm{O}_{4}$ の三重点の温度は約 $615^{\circ} \mathrm{C}$ で あるが，山崎，池田によれば7)，Mrowec らの実験 ${ }^{91} に$

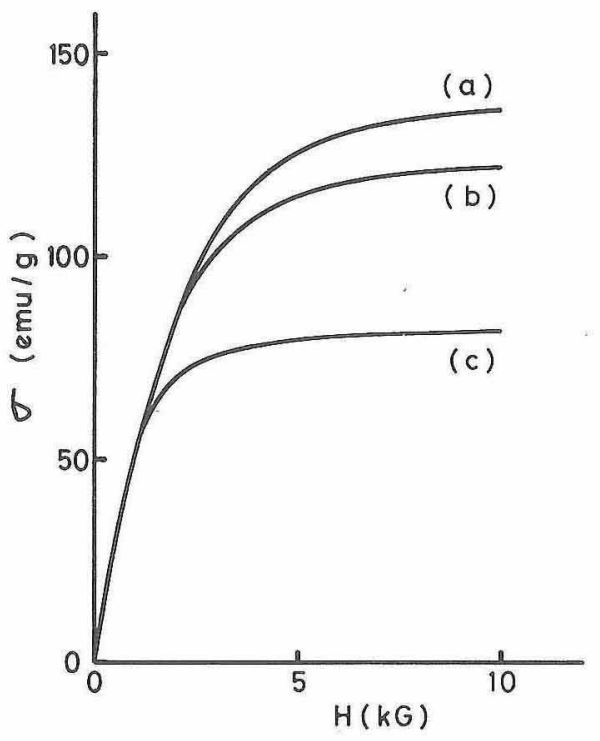

Fig.6. Magnetization curve of hydrothermal reaction sintered permalloy-oxide composites.

(a) $\mathrm{Fe}-47 \mathrm{wt} \% \mathrm{Ni}$ permalloy: starting material

(b) Permalloy-magnetite : $800^{\circ} \mathrm{C}, 100 \mathrm{MPa}, 60 \mathrm{~min}$, 10 wt $\% \mathrm{H}_{2} \mathrm{O}$

(c) Permalloy-wustite : $1000^{\circ} \mathrm{C}, 100 \mathrm{MPa}, 60 \mathrm{~min}, 10$ wt $\% \mathrm{H}_{2} \mathrm{O}$

基づいて三重点は $575^{\circ} \mathrm{C}$ であるとしている。また平野 らの実験 ${ }^{5)}$ では $1000 \mathrm{~kg} / \mathrm{cm}^{2}$ の水熱条件では $650^{\circ} \mathrm{C}$ まで マグネタイトのみが得られたとしている。これらの差は 圧力の違いによるものかもしれない。

次に $\mathrm{H}_{2} \mathrm{O}$ の平衡解離圧を求めた。

$$
\mathrm{H}_{2} \mathrm{O}=\mathrm{H}_{2}+\frac{1}{2} \mathrm{O}_{2}
$$

において，自由エネルギーは

$$
\begin{aligned}
& \Delta G_{\mathrm{T}}^{\circ}=-R T \ln K_{\mathrm{f}} \\
& K_{\mathrm{f}}=K_{\nu} \cdot K_{\mathrm{P}}
\end{aligned}
$$

で与えられる。ここで

$$
\begin{aligned}
& K_{\mathrm{f}}=f_{\mathrm{H}_{2}} \cdot f_{\mathrm{O}_{2}}^{1 / 2} / f_{\mathrm{H}_{2} \mathrm{O}} \\
& K_{\nu}=\nu_{\mathrm{H}_{2}} \cdot \nu_{\mathrm{O}_{2}}^{1 / 2} / \nu_{\mathrm{H}_{2} \mathrm{O}} \\
& K_{\mathrm{P}}=p_{\mathrm{H}_{2}} \cdot p_{\mathrm{O}_{2}}^{1 / 2} / p_{\mathrm{H}_{2} \mathrm{O}}
\end{aligned}
$$

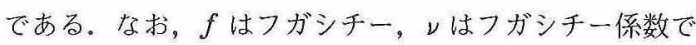
ある. $p_{\mathrm{H}_{2}}=2 p_{0_{2}}$ と仮定するならば，系の圧力が 0.1 $\mathrm{MPa}$ のとき $K_{\nu}=1$ であることを用いて $\log \left(p_{\mathrm{H}_{2} \mathrm{O}} / p_{\mathrm{H}_{2}}\right)$ が求められる，結果は図 7 の破線 (a) である。系の圧 力が $100 \mathrm{MPa}$ のとさは，換算温度 $T_{\mathrm{R}}$ と換算圧力 $P_{\mathrm{R}}$ か ら $K_{\nu}$ を求め ${ }^{10)} こ の$ 值を用いて $\log \left(p_{\mathrm{H}_{2} \mathrm{O}} / p_{\mathrm{H}_{2}}\right)$ が求めら れる. 結果は破線（b）である。熱力学的にはこの破線 上の組成が試料最表面に生成することになるが，本実験 において， $\mathrm{Fe}_{2} \mathrm{O}_{3}$ はX線回折線では確認できなかった。 これは，本実験では，反応が進むと $\mathrm{H}_{2}$ ガスがカプセル 内で発生するが，系外八出る速度が小さいために $p_{\mathrm{H}_{2}}$ が 上昇し， $\log \left(p_{\mathrm{H}_{2} \mathrm{O}} / p_{\mathrm{H}_{2}}\right)$ が小さくなり，安定相が $\mathrm{Fe}_{3} \mathrm{O}_{4}$ 


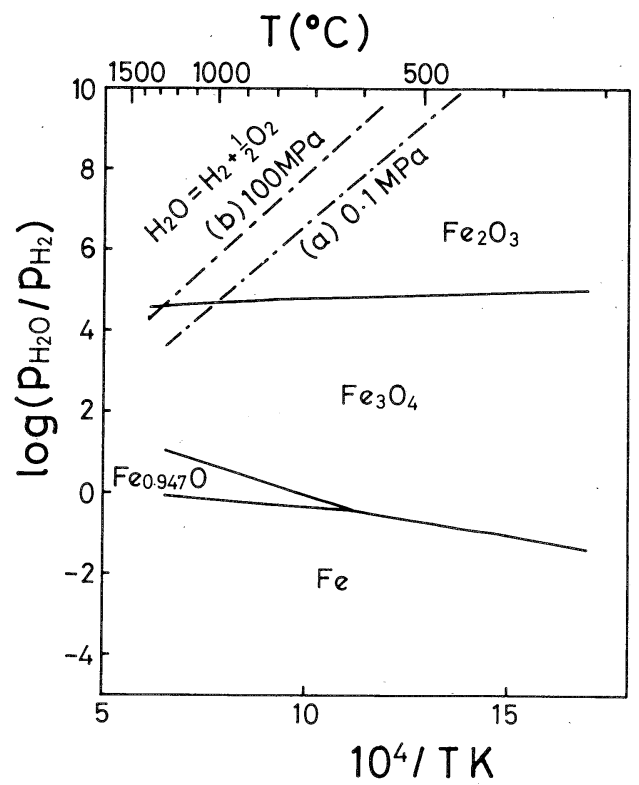

Fig. 7. Equilibrium diagram of $\mathrm{Fe}-\mathrm{O}-\mathrm{H}$ system.

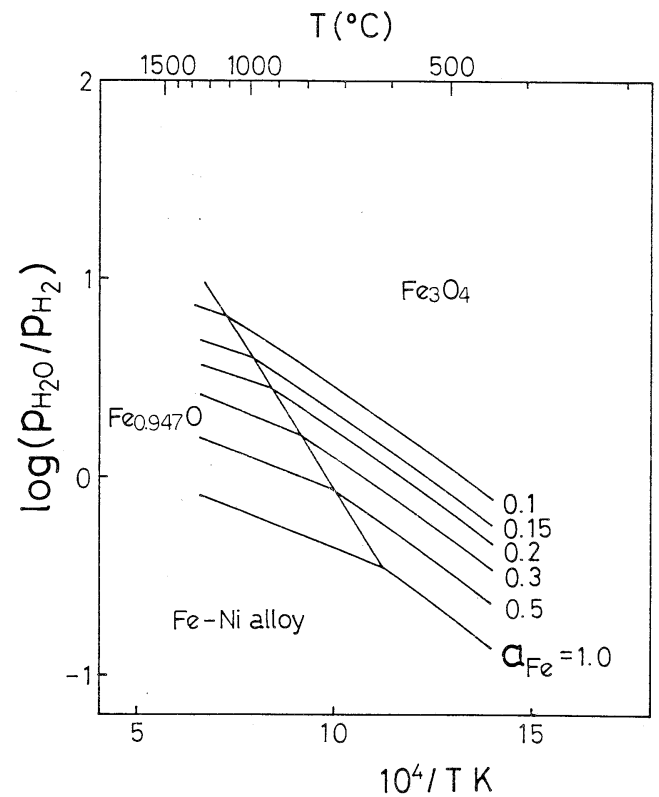

Fig. 8. Triple point of $\mathrm{Fe}-\mathrm{Ni}$ alloy-wüstite-magnetite as a function of the activity of iron $\left(a_{\mathrm{Fe}}\right)$ in the $\mathrm{Fe}-\mathrm{Ni}$ alloy.

になったと考えられる，一方，処理時間が長くなるとウ スタイトの量が増えるのは，カプセル内の $\mathrm{H}_{2} \mathrm{O}$ がすべ て反応し，焼結したのちも合金相から酸化物相への $\mathrm{Fe}$ の供給が続き $\mathrm{Fe}_{3} \mathrm{O}_{4}$ が $\mathrm{FeO}$ に還元されるためと考えら れる。

本実験で用いている Fe-Ni 合金中では Fe の活動度 は $a_{\mathrm{Fe}} \neq 1$ であり, $\mathrm{Fe}$ の選択的酸化による $\mathrm{Fe}$ の濃度減
少に伴い $a_{\mathrm{Fe}}$ も減少する。そこで (11) 式，(12) 式で $a_{\mathrm{Fe}} \neq 1$ として $\log \left(p_{\mathrm{H}_{2} 0} / p_{\mathrm{H}_{2}}\right)$ を求めたものが図 8 である. $a_{\mathrm{Fe}}$ の減少に伴い $\log \left(p_{\mathrm{H}_{2} \mathrm{O}} / p_{\mathrm{H}_{2}}\right)$ が増加し, 酸化されに くくなっていることが分かる。また，それに伴いウス夕 イトの安定領域が高温側へ移動している.これは既報 ${ }^{11}$ の $\Gamma \mathrm{Fe}-\mathrm{Ni}$ 合金では $\mathrm{Ni}$ 量が増加すると $\mathrm{FeO}$ の厚さが 減少し, ある程度以上では全く消失する.」現象と一致 している. 本実験において, $800^{\circ} \mathrm{C}$, 及び $900^{\circ} \mathrm{C}$ で酸化 物がマグネタイトのみであった試料では合金-酸化物界 面における合金組成に関する三重点が各々の温度よりも 高い温度に位置していたと考えられる。

\section{5. 総 括}

（） $\mathrm{Fe}-\mathrm{Ni}$ 合金と $\mathrm{H}_{2} \mathrm{O}$ を白金カプセル中で加熱加 圧処理する水熱反応焼結法で $(\mathrm{Fe}-\mathrm{Ni})$-鉄酸化物複合焼 結体を得ることができる。

( ii ） $\mathrm{H}_{2} \mathrm{O}$ の量を制御することによって合金と酸化 物の量比を制御することができる.

( iii ) $\mathrm{H}_{2} \mathrm{O}$ の量, 処理温度, 処理時間により酸化物 相中の構成比 $\mathrm{FeO} / \mathrm{Fe}_{3} \mathrm{O}_{4}$ 比を制御することが可能であ る。

(iv) 生成する鉄酸化物相は, $p_{\mathrm{H}_{2} \mathrm{O}} / p_{\mathrm{H}_{2}}$ 比亡合金中の 鉄の活動度で決定される。

\section{文献}

1) S. Sōmiya, M. Yoshimura, H. Toraya, E. Tani, M. Suzuki, S. Kikugawa and T. Hattori, Proc. First Int. Symp. Ceramic Components for Engine, Ed. by S. Sōmiya, E. Kanai and K. Ando, KTK Sci. Pub. Co., Tokyo, and D. Reidel Pub. Co., Dordrecht (1984).

2) M. Yoshimura and S. Sōmiya, Am. Ceram. Soc. Bull. 59, $246(1980)$

3) S. Hirano and S. Sōmiya, J. Am. Ceram. Soc., 59, 534 (1976).

4) M. Yoshimura, S-T. Song and S. Sōmiya, 3rd Int. Conf. on Ferrites, Kyoto, Sept. 1980, 429-32, Ed. by H. Watanabe, S. Iida and M. Sugimoto, Center For Academic Publications Japan (1981).

5) 平野眞一, 宗宮重行, 第 12 回梥業基礎討論会講演要旨集, p. 34, 1974, Jan. 30 .

6) 本間, 木村, 川崎, 副島, 分析化学, 23，591 (1974).

7) 山崎桓友, 池田雄二, “金属材料の高温酸化亡高温腐食”, 腐食防食協会編，丸善（1982）p. 136-37.

8) D. R. Stull and H. Prophet, JANAF Thermochemical Tables Second Edition, U.S. Government Printing Office, Washington, D.C. (1971).

9) S. Mrowec and T. Werber, Gas Corrosion of Metals, National Bureau of Standards and the National Science Foundation, Washington, D. C., The Foreign Scientific Publications, Department of the National Center for Scientific Technical and Economical Information, Warsaw, Poland (1979) p. 417.

10）ムーア, “物理化学 (上)”, 東京化学同人 (1974) p. 309

11）新居和嘉，“金属材料の高温酸化亡高温腐食”，腐食防食 協会編，丸善（1982）p. 29. 